\title{
BADANIE ŚWIADOMOŚCI STUDENTÓW UNIWERSYTETU ŁÓDZKIEGO W ZAKRESIE PRZESTĘPSTW KARUZELOWYCH W PODATKU OD TOWARÓW I USŁUG
}

\author{
Tomasz Saganowski \\ Wydział Ekonomiczno-Socjologiczny, Uniwersytet Łódzki
}

\section{Streszczenie}

Podatek od towarów i usług już od jego wprowadzenia, czyli 1993 roku stanowi istotne źródło dochodów budżetu państwa. Polska przygotowywała się do przystąpienia do Unii Europejskiej, dlatego musiała przebudować system podatkowy w kierunku dostosowania go do wymogów gospodarki rynkowej. W efekcie zmian, został zlikwidowany system poboru podatku od towarów i usług importowanych na terenie państwa, w którym dokonywane są rozliczenia podatku VAT, w zakresie wewnątrzwspólnotowego obrotu towarowego. Przyczyniło się to do powstania przestępczego mechanizmu - karuzeli podatkowej, polegającej na przepływie towarów pomiędzy państwami członkowskimi Unii Europejskiej w bardzo skomplikowany sposób. Finalnym etapem karuzeli podatkowej jest wyłudzanie zwrotu podatku oraz uchylanie się od jego płacenia. Celem artykułu jest zbadanie oceny świadomości studentów Uniwersytetu Łódzkiego o kierunkach ekonomicznych i prawniczych odnośnie przestępstw karuzelowych, które są przyczyną luki budżetowej oraz zagrożeniem dla uczciwych przedsiębiorców pozbawiając ich odliczeń podatku naliczonego. W artykule postawiona została następująca hipoteza badawcza, czy dotychczasowy program nauczania na kierunkach ekonomicznych i prawniczych Uniwersytetu Łódzkiego jest wystarczająco odpowiedni i należycie uświadamia studentów przed mechanizmem wykorzystywanym przez nieuczciwych przedsiębiorców. Przeprowadzone zostały badania wśród studentów Uniwersytetu Łódzkiego, studiujących kierunki ekonomiczne i prawnicze. W opracowaniu podjęto próbę, pozwalającą ocenić, czy dotychczasowy program nauczania Uniwersytetu Łódzkiego przekazuje odpowiednią wiedzę dotyczącą karuzel podatkowych. Studenci kierunków ekonomicznych i prawniczych powinni być przygotowani na tego typu sytuacje oraz uczuleni na dokładne weryfikowanie nowych kontrahentów. Znając mechanizm wyłudzania podatku od towarów i usług metodą karuzelową, w znacznym stopniu zmniejszy się zjawisko występujące w gospodarce, nie tylko polskiej, ale również europejskiej.

Słowa kluczowe: karuzela podatkowa, podatek VAT, Uniwersytet Łódzki, podatek należny, podatek naliczony.

JEL Class: H2, H26, G28. 


\section{ISTOTA PODATKU OD TOWARÓW I USŁUG}

Ustawa o podatku od towarów i usług wprowadza pojęcie podatku naliczonego oraz podatku należnego. Podatek należny jest to łączna suma kwot podatku wynikająca $\mathrm{z}$ dostaw towarów lub świadczenia usług przez przedsiębiorców. $\mathrm{Z}$ kolei podatek naliczony jest to suma kwot podatku wynikająca $\mathrm{z}$ otrzymanych faktur przez podatnika $\mathrm{z}$ tytułu nabycia towarów lub usług. W sytuacji, kiedy zakup towarów jest importem, przed obliczeniem podstawy opodatkowania, należy obliczyć cło oraz akcyzę. Zgodnie z art. 86 ust. 1 ustawy o VAT podatnik ma prawo do obniżenia kwoty podatku należnego o kwotę podatku naliczonego.

$\mathrm{Na}$ rysunku 1 został zaprezentowany przykład regulowania zobowiązań z Urzędem Skarbowym.

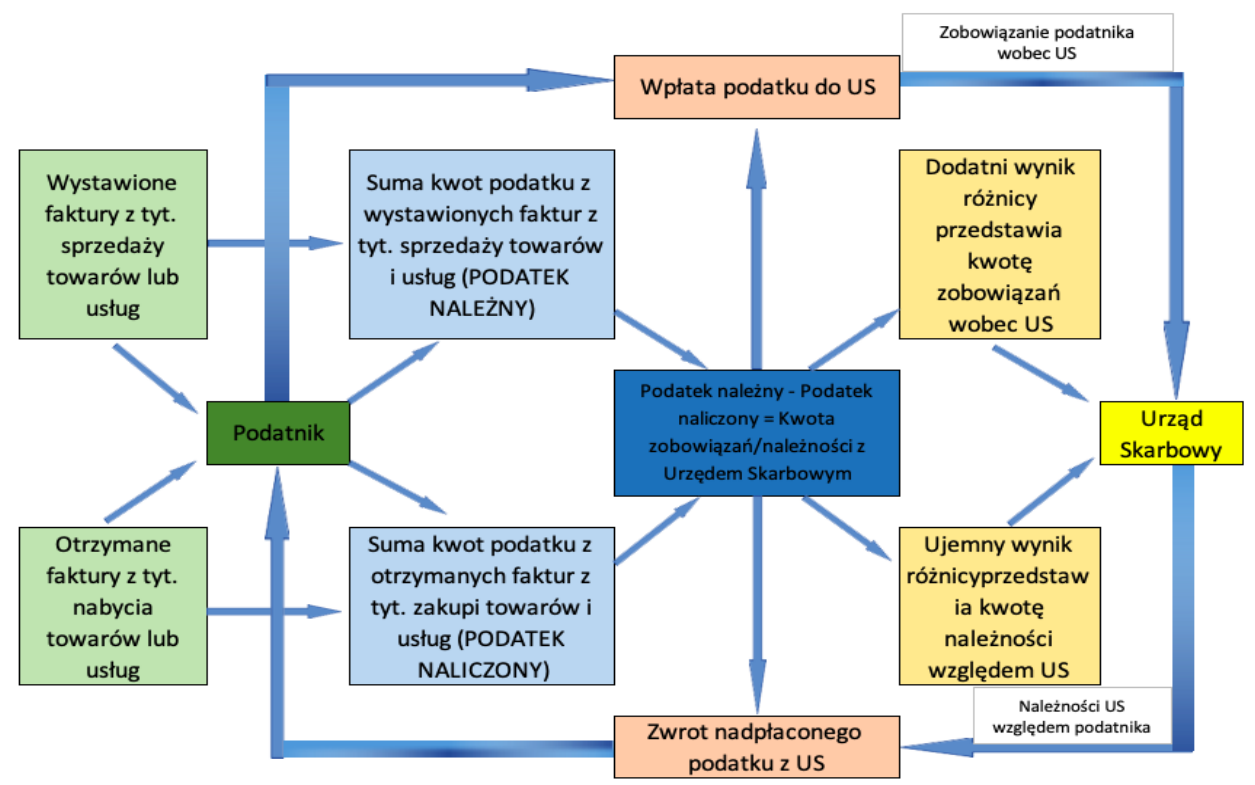

Rysunek 1. Proces rozliczania podatnika z Urzędem Skarbowym

Źródło: opracowanie własne.

Na rysunku 1 został przedstawiony sposób rozliczania podatnika z Urzędem Skarbowym. Analizując powyższy diagram można dostrzec dwie sytuacje. W pierwszej sytuacji suma kwot podatku $\mathrm{z}$ otrzymanych faktur zakupu przewyższa sumę kwot podatku $z$ wystawionych faktur sprzedaży. W takiej sytuacji podatnik otrzyma z Urzędu Skarbowego zwrot nadwyżki zapłaconego podatku. $\mathrm{W}$ drugiej sytuacji suma kwot $\mathrm{z}$ wystawionych faktur sprzedaży przez podatnika jest wyższa, niż suma kwot podatku $\mathrm{z}$ otrzymanych faktur zakupu. W takim 
przypadku podatnik jest zobowiązany do uiszczenia opłaty $\mathrm{w}$ odpowiednim Urzędzie Skarbowym.

Podatek posiada charakterystyczną budowę, która służy do przedłożenia myśli podatkowej na język przepisów prawnych. Określają one relacje pomiędzy organami podatkowymi, działającymi w imieniu państwa, oraz osobami zobowiązanymi do zapłaty podatku. Pozwala na to odróżnienie podatków między sobą [Kostecki 1985: 151].

Przedmiot podatku, obejmujący sytuacje, zjawisko, stan prawny lub faktyczny, w którym ustawodawca łączy obowiązek uiszczenia zobowiązania podatkowego [Harasimowicz 1988: 115]. Jest on rzeczą lub zdarzeniem, z którego wynika powstanie obowiązku podatkowego np. uzyskanie przychodu, dochodu, wydatki, przyrost majątku. Przedmiot podatku jest ściśle powiązany ze źródłem podatku, ponieważ źródło podatku wynika z dochodu i majątku [Wolański 2016: 22].

Wewnątrzwspólnotowe nabycie towarów (WNT) jest to nabycie prawa do rozporządzenia towarami jak właściciel, które w wyniku dokonanej dostawy są transportowane na terytorium państwa członkowskiego Unii Europejskiej inne niż terytorium państwa członkowskiego rozpoczęcia wysyłki lub transportu przez dokonującego dostawy, nabywcę towarów lub na ich rzecz.

Transakcja stanowi WNT, jeśli nabywcą towarów jest:

- osoba prawna niebędąca podatnikiem (pod pewnymi warunkami);

- podatnik VAT - osoba prawna, jednostka organizacyjna niemająca osobowości prawnej, bądź osoba fizyczna wykonująca samodzielnie działalność gospodarczą bez względu na rezultat tej działalności - lub podatnik podatku od wartości dodanej innego kraju wspólnoty, o ile nabywane towary mają służyć działalności gospodarczej podatnika.

Do transakcji WNT konieczne jest, aby dokonujący dostawy towarów był podatnikiem VAT lub podatnikiem podatku od wartości dodanej.

Wewnątrzwspólnotowa dostawa towarów (WDT) jest to wywóz towarów z terytorium kraju o wykonaniu czynności opodatkowanych na terytorium państwa członkowskiego inne niż terytorium kraju.

Transakcja WDT jest uznawana, gdy nabywca towarów jest:

- podatnikiem podatku od wartości dodanej zidentyfikowanej na potrzeby transakcji wewnątrzwspólnotowych na terytorium państwa członkowskiego innym niż terytorium kraju;

- osobą prawną niebędącą podatnikiem podatku od wartości dodanej, która jest zidentyfikowana na potrzeby transakcji wewnątrzwspólnotowych na terytorium państwa członkowskiego innym niż terytorium kraju.

Za WDT uznaje się również przemieszczenie przez podatnika lub na jego rzecz towarów należących do jego przedsiębiorstwa $z$ terytorium kraju na terytorium państwa członkowskiego inne niż terytorium kraju, które zostały przez tego podatnika na terytorium kraju w ramach prowadzonego przez niego przedsię- 
biorstwa wytworzone, wydobyte, nabyte, $\mathrm{w}$ tym również $\mathrm{w}$ ramach wewnątrzwspólnotowego nabycia towarów, albo sprowadzone na terytorium kraju w ramach importu towarów, jeżeli mają służyć działalności gospodarczej podatnika.

\section{CHARAKTERYSTYKA PRZESTĘPSTW KARUZELOWYCH}

Karuzela podatkowa jest przestępczym mechanizmem polegającym na wyłudzeniu nienależnego zwrotu towarów. Jej głównym celem jest uchylanie się od opodatkowania oraz wyłudzenia zwrotu podatku VAT. W obrocie towarowym wykorzystywane są nie tylko realne przepływy towarów, ale również, nieuczciwi przedsiębiorcy wystawiają fikcyjne faktury, które bezpodstawnie generują wartość podatku VAT.

Oszuści podatkowi najczęściej wybierają towar o małych gabarytach, a znaczącej wartości. Jest tak, ponieważ małe artykułu zazwyczaj są łatwiejsze w transporcie. Nieuczciwi przedsiębiorcy tworzą karuzelę, w której towar przepływa przez szereg podmiotów. Do stworzenia owej karuzeli początkowym podmiotem jest tzw. „spółka wiodąca”. Spółka ta, w głównej mierze jest odpowiedzialna za zorganizowanie kanału dystrybucyjnego. Pełni również dwie ważne funkcje. Jedną z nich jest dostarczenie towarów dla tzw. „znikających handlowców". Kolejnym zadaniem takiej spółki jest nabycie towarów w ramach wewnątrzwspólnotowego nabycia towarów lub eksportu towarów dla tzw. „brokerów". Spółka wiodąca ulokowana jest poza granicami państwa, na którego terytorium jest popełniane przestępstwo skarbowe. Oznacza to, że jest poza odpowiedzialnością karną państwa, w którym dochodzi do wyłudzenia podatku VAT. Zazwyczaj spółki wiodące prawidłowo rozliczają się z tytułu podatku VAT, aby utrudnić wykrycie nieuczciwego precedensu. Kolejnym podmiotem w karuzeli podatkowej jest już wcześniej wspomniany „znikający handlowiec”. Należy on do podmiotów przestępczych, który jest prowadzony przez tzw. „słupy". Są to zazwyczaj ludzie bez majątków, którzy za niewielkim wynagrodzeniem podpisują wskazane dokumenty. „Ludzie - słupy” nie są świadomi popełniania czynu karalnego. Przesiębiorstwa, które zakupują towary od znikającego handlowca są nazywani „buforami”. W jednej karuzeli podatkowej takich podmiotów jest nawet kilkadziesiąt, aby utrudnić wykrycie przestępstwa przez organy ścigania. „Bufor” prowadzi działalności zgodnie z prawem [Kozub-Skalska 2017: 146-147]. Uproszczony schemat przestępstw karuzelowych został przedstawiony na rys. 2 . 


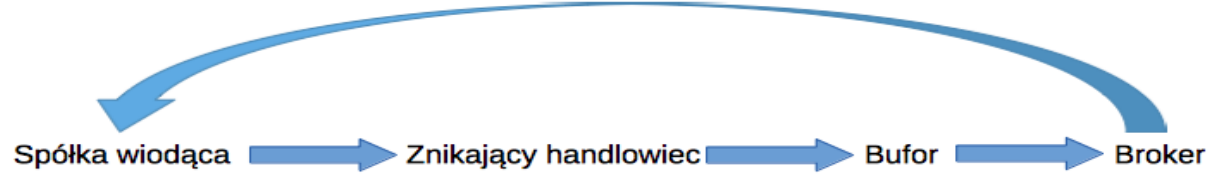

Rysunek 2. Łańcuch transakcji w przestępstwach karuzelowych

Źródło: opracowanie własne.

Spółka wiodąca podczas sprzedaży towarów nie nalicza podatku w ramach wewnątrzwspólnotowej wymiany towarów. Towary te są zakupione przez znikających handlowców, którzy po sprzedaży towarów buforom naliczają podatek VAT. Po otrzymaniu zapłaty od buforów nie odprowadzają podatku VAT należnego do Urzędu Skarbowego tylko likwidują działalność gospodarczą. Bufor, który jest uczciwym przedsiębiorcom, nie jest świadomy, że bierze udział $\mathrm{w}$ przestępczym precedensie. Zgodnie z prawem, po dalszej sprzedaży towarów dla brokerów, rozlicza się prawidłowo z Urzędem Skarbowym. Towary następnie są ponownie kupowane przez spółkę wiodącą w ramach wewnątrzwspólnotowej wymiany towarów. Oznacza to ponowne zwolnienie z VAT-u, a broker, jako kolejny podmiot zwraca się z prośbą o zwrot podatku, po czym usuwa swoją działalność handlową. Po przeprowadzeniu takiego schematu karuzeli, do państwa nie jest odprowadzony należyty podatek, a dodatkowo nieuczciwi przedsiębiorcy zwracają się z prośbą o zwrot podatku. Naraża to państwo na ogromne straty w budżecie państwa.

Problem nadużyć podatkowych dotkliwie naraża uczciwych przedsiębiorców na niezrównoważone konkurowanie. Można to dostrzec na podstawie dwóch aspektów [Sokołowski i Sosnowski 2015: 51]:

- nieuczciwi przedsiębiorcy zazwyczaj sprzedają towary taniej o wysokość podatku od towarów i usług, którego w przeszłości nie odprowadzili; oznacza to problem z popytem na dany produkt lub usługę bez obniżenia cen, często do poziomu dumpingowego;

- uczciwi przedsiębiorcy są bardziej podatni na kontrole ze strony Urzędu Skarbowego; ich rozliczenia mogą być zakwestionowane, gdy przedsiębiorca dokonywał wymiany towarów z grupami przestępczymi; brak dostatecznej wiedzy o kontrahencie może spowodować, że przedsiębiorca bez świadomości może uczestniczyć w łańcuchu podatkowym; sankcją dla owego przedsiębiorcy jest brak możliwości odliczenia podatku VAT naliczonego, co w konsekwencji może powodować liczne problemy z regulowaniem zobowiązań, a nawet do ogłoszenia bankructwa. 


\section{SPOSOBY OGRANICZANIA NADUŻYĆ W PODATKU VAT}

Wartość luki budżetowej wynikającej z działalności przestępczej wynikającej z przestępczości podatkowej na koniec 2016 roku szacowana była na 37 mld PLN, czyli 2,5\% PKB [Godusławski, Chądzyński, 2018]. Pośrednio na wyłudzeniach tracą wszyscy obywatele kraju. Umniejszone przychody Skarbu Państwa z tytułu bezprawnie wyłudzonego podatku VAT powodują uszczuplenie budżetu państwa, co prowadzi do mniejszych wydatków budżetowych. Mniejsze zasoby środków finansowych budżetu państwa nie prowadzą do dodatkowych inwestycji, np. budowy autostrad, szpitali, ośrodków sportowych. Prowadzi to do zmniejszenia popytu, następnie ograniczenia produkcji i jest przyczyną wzrostu bezrobocia. To powoduje, że pośrednio na tego rodzaju przestępstwach traci każdy obywatel. Hamuje to gospodarkę ekonomiczną naszego kraju, innowacyjne projekty rozwojowe, a co za tym idzie poziom życia mieszkańców kraju. Dodatkowym aspektem są liczne problemy przedsiębiorców, którzy poprzez zostanie ofiarą karuzeli podatkowej mają ogromne problemy z sytuacją finansową przedsiębiorstwa, co często prowadzi do upadłości. Bycie podmiotem w łańcuchu przestępczym pozbawia ich możliwości odliczenia podatku VAT naliczonego.

Działania Ministerstwa Finansów, które poprawiają skuteczność zwalczania oszustw podatkowych w podatku od towarów i usług zostały uchwalone 26 lipca 2013 roku, natomiast weszły w życia 1 października 2013 roku. Polegają na [Paduch 2016: 627]:

- rozwoju działań z administracjami podatkowymi krajów członkowskich Unii Europejskiej,

- rozszerzeniu zakresu stosowania systemu odwrotnego obciążenia na obrót wybranymi wyrobami z miedzi i stali; również na dodatkowe grupy towarów stanowiących surowce wtóre i odpady (załącznik 11, Ustawa o VAT);

- likwidacji możliwości kwartalnego rozliczania podatku VAT przez podatników, którzy dokonują wymiany towarami wrażliwych (załącznik 13, Ustawa o VAT);

- wprowadzeniu instytucji odpowiedzialności podatkowej nabywcy za zobowiązania podatkowe VAT sprzedawcy; dotyczy to dóbr wrażliwych, niektórych wyrobów stalowych, paliwa, złota nieobrobionego.

Kluczowym składnikiem budżetu Rzeczypospolitej Polskiej są wpływu z podatku VAT. Ważnym zadaniem jest skuteczne przeciwdziałanie oszustom podatkowym, które powstały wskutek niedopasowanej konstrukcji podatku od towarów i usług. Należy pamiętać, że zmiany, które zostały wprowadzone są rozwiązaniami systemowymi, a nie próbami doraźnego likwidowania przestępczości w sektorach gospodarki. 


\section{WYNIKI BADANIA ANKIETOWEGO I ANALIZA}

W artykule została postawiona następująca hipoteza badawcza, iż dotychczasowy program nauczania na kierunkach ekonomicznych i prawniczych Uniwersytetu Łódzkiego jest wystarczająco odpowiedni i należycie uświadamia studentów przed mechanizmem wykorzystywanym przez nieuczciwych przedsiębiorców. Szczególnie została sprawdzona wiedza z zakresu podatku VAT, znajomości metod karuzelowych, skali ich występowania oraz konsekwencji bycia podmiotem w przestępczym łańcuchu. Do badania została wykorzystana metoda ankietowa, w której odpowiedzi udzieliło 336 studentów i absolwentów Uniwersytetu Łódzkiego z Wydziału Ekonomiczno-Socjologicznego, Zarządzania oraz Prawa i Administracji, którzy studiowali, bądź nadal studiują kierunki ekonomiczne lub prawnicze.

Ankietowani odpowiedzieli na 12 pytań związanych z podatkiem VAT oraz przestępstwami karuzelowymi. W badaniu, Wydział Ekonomiczno-Socjologiczny reprezentowało 144 studentów, Wydział Zarządzania 107 studentów, Wydział Prawa i Administracji 57 studentów oraz dodatkowo 28 absolwentów Uniwersytetu Łódzkiego.

$\mathrm{Na}$ pytanie dotyczące istnienia przestępstw karuzelowych 196 badanych $(58,3 \%)$ odpowiedziało twierdząco, jednakże tylko 16 ankietowanych $(4,8 \%)$ potrafiło krótko wyjaśnić na czym polegają. Oznacza to, że mimo wielu apelacji ze stron medialnych (telewizji, pracy, radio) oraz studiowania kierunków ekonomicznych i prawniczych jest 140 studentów (41,6\%), którzy nigdy nie spotkali się z terminem przestępczości karuzelowej.

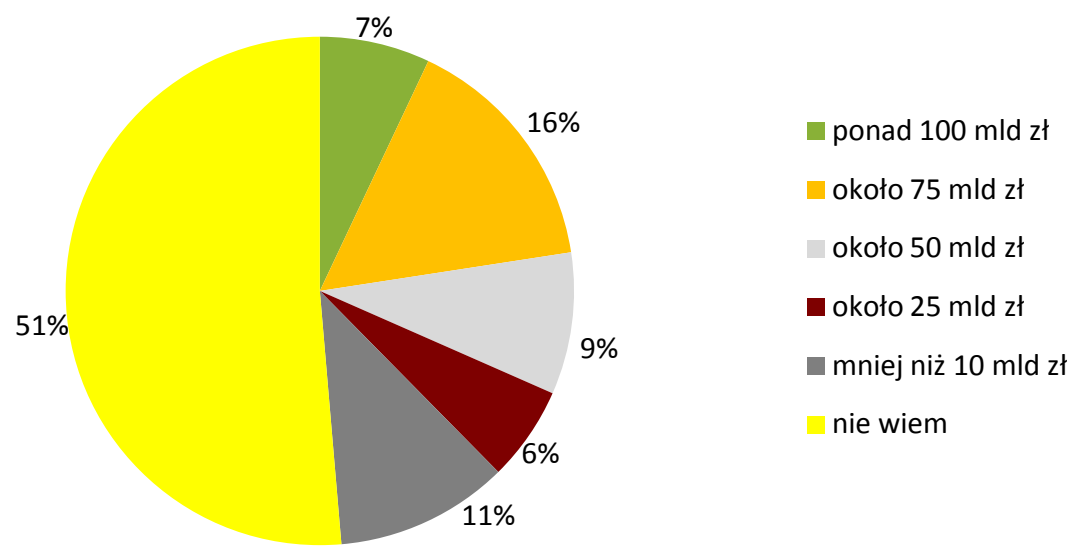

Wykres 1. Szacowana wielkość luki budżetowej w 2017 roku spowodowana przestępczością karuzelową przez studentów i absolwentów Uniwersytetu Łódzkiego.

Źródło: opracowanie własne. 
Ankietowani zostali również zapytani o wielkość strat spowodowanych przestępstwami karuzelowymi w 2017 roku. Wyniki przedstawia wykres 1.

Respondenci zapytani o skalę przestępstw podatkowych w ciagu roku, w większości wykazali się brakiem wiedzy. Nie podjęli również próby oszacowania wielkości luki (51,35\% studentów). Mogło być to spowodowane brakiem podania luki budżetowej z poprzednich lat. W przypadku podania wielkości luk z poprzednich lat, autor ankiety mógłby spodziewać się efektu zakotwiczenia.

W kolejnym pytaniu, badani zostali zapytani o znajomość sankcji dla przedsiębiorców. Tylko 14 ankietowanych odpowiedziało, że zna konsekwencje bycia podmiotem w przestępstwach karuzelowych. W następnym pytaniu, ankietowani zostali poproszeni o wypisanie przykładowych konsekwencji bycia podmiotem w przestępczym łańcuchu karuzelowym. Respondenci nie byli w stanie odpowiedzieć na to pytanie.

W kolejnych pytaniach, autor ankiety, podjął próbę oceny oraz chęci poznania mechanizmu przestępstw karuzelowych wśród ankietowanych. Respondenci zostali zapytani, czy w programie nauczania na kierunkach ekonomicznych oraz prawniczych Uniwersytetu Łódzkiego był poruszany problem przestępstw karuzelowych. Spośród grupy 336 studentów i absolwentów UŁ, 278 z nich $(82,7 \%)$ odpowiedziało przecząco na pytanie. Pozostali, czyli grupa 58 badanych $(17,2 \%)$ nie potrafili udzielić odpowiedzi na to pytanie. Mogło to być spowodowane nieobecnością ankietowanego na zajęciach, gdzie była poruszana kwestia przestępstw karuzelowych. Nikt z badanych nie odpowiedział twierdząco na to pytanie, co oznacza, że tak poważny problem ekonomiczny i prawny nie był w ostatnich latach poruszany, mimo narastającej skali zjawiska w poprzednich latach.

W kolejnym pytaniu, autor chcąc zweryfikować chęci poznawcze wśród badanych dotyczących zagadnień przestępczości podatkowej, postawił pytanie o skłonność do omówienia problemu ekonomiczno-prawnego na zajęciach w programie nauczania. Twierdzących odpowiedzi było aż 322 (95,8\%). Oznacza to, że studenci pragną poznać szczegółowo mechanizm przestępstw karuzelowych. Sygnalizuje to chęci przyswojenia metod oraz sposobów zwalczania skali przestępstw, a także zaznajomienia się ze sposobami wyłudzania podatku VAT przez przestępców.

Ostatnie pytanie, które autor zadał studentom oraz absolwentom, dotyczyło sprawdzenia nowych kontrahentów pod względem wiarygodności przedsiębiorstwa w przypadku prowadzenia w działalności gospodarczej. Wśród badanych, aż 243 z nich (72,3\%) potwierdziło dokładniejszą weryfikację nowych kontrahentów, z którymi w przyszłości przedsiębiorstwo planuje współpracę. Przecząco na to pytanie odpowiedziało 14 respondentów $(4,1 \%)$, natomiast pozostali, czyli 79 ankietowanych $(23,5 \%)$ nie określiło swojej opinii. Może to być spowodowane niedostateczną wiedzą na temat przestępstw karuzelowych. 


\section{PODSUMOWANIE}

Znaczący wzrost wymiany towarowej z zagranicą, oprócz pozytywnych czynników, wywołuje również takie, które negatywnie wpływają na gospodarkę kraju. W wyniku zorganizowanych działalności grup przestępczych, budżet państwa traci ogromne środki pieniężne, które go nie zasilą. Dodatkowo utrudnia to konkurowanie na rynku uczciwym przedsiębiorcom, prowadząc ich działalność do kryzysu, a nawet do bankructwa. Do zniwelowania problemu potrzebna jest odpowiednia edukacja studentów, którzy w przyszłości będą pracować w przedsiębiorstwach o zróżnicowanym profilu lub sami będą takowe prowadzić. Aby pozbyć się problemu przestępczości podatkowej, oprócz odpowiedniej edukacji, potrzebna jest również zmiana systemu rozliczania podatników oraz zmiany przepisów prawnych. Są tą działania, które nie jest łatwo wprowadzić, a dodatkowo każda zmiana jest długotrwała.

Podsumowując wyniki badania ankietowego należy stwierdzić, iż dotychczasowy program nauczania Uniwersytetu Łódzkiego na kierunkach ekonomicznych i prawniczych nie porusza poważnego problemu, jakim jest przestępczość podatkowa. Studenci oraz absolwenci kończąc studia o profilu ekonomicznym lub prawniczym, powinni posiadać dostateczną wiedzą na temat karuzel podatkowych. Wśród badanych, większość z nich wykazała chęci poznania owego problemu. Oznacza to, iż do zwiększenia świadomości wśród przestępczości podatkowej, dobrym rozwiązaniem byłoby wprowadzenie odpowiednich zajęć tematycznych do siatki zajęć. Następnie, po wprowadzeniu zajęć na temat karuzel podatkowych należałoby sprawdzić wiedzę wśród studentów i absolwentów, przeprowadzając odpowiednią ankietę po ukończeniu toku studiów. Pozwoliłoby to na zweryfikowanie świadomości wśród przyszłych pracowników lub przedsiębiorców. Uzyskane wyniki należałoby porównać z dotychczasowymi oraz oddać do ponownej analizy.

\section{BIBLIOGRAFIA}

Brzeziński B., Dębowska-Romanowska T., Kalinowski M., Wójtowicz W., 2000, Prawo finansowe, C. H. Beck, Warszawa.

Harasimowicz J., 1988, Finanse i prawo finansowe, PWE, Warszawa.

Kosacka-Łędzewicz D., 2001, Podatek od towarów i uslug. Poradnik praktyczny, Dom Wydawniczy ABC, Warszawa.

Kostecki A., 1985, Elementy konstrukcji instytucji podatku, Ossolineum.

Kozub-Skalska S., 2017, Mechanizm przestępstw karuzelowych i metody ich ograniczania, Uniwersytet Ekonomiczny w Katowicach, Katowice..

Nykiel W., 2011, Polskie prawo podatkowe, Difin, Warszawa. 
Pauch D., 2016, Transakcja karuzelowa jako forma oszustwa w podatku od wartości dodanej, Uniwersytet Szczeciński. Wydział Zarządzania i Ekonomiki Usług, Szczecin.

Sokołowski J., Sosnowski M., 2015, Finanse publiczne, Wydawnictwo Uniwersytetu Ekonomicznego we Wrocławiu, Wrocław.

Wolański R., 2016, System podatkowy w Polsce, Wolters Kluwer SA, Warszawa.

\title{
THE STUDY OF THE STUDENTS' AWARENESS OF THE UNIVERSITY OF LODZ IN THE FIELD OF CAROUSEL CRIMES IN THE TAX ON GOODS AND SERVICES
}

\begin{abstract}
The tax on goods and services since its introduction in 1993 is an important source of revenue for the state budget. Poland was preparing to join the European Union, which is why it had to rebuild the tax system in order to adapt it to meet the requirements of the market economy. As a result of the changes, the system of collecting the tax on goods and services imported in the territory of the country in which VAT settlements are made in the scope of intra-Community trade in goods has been abolished. This contributed to the creation of a criminal mechanism - a carousel tax, consisting in the movement of goods between the Member States of the European Union in a very complicated way. The final stage of the carousel tax is extorting the tax refund and avoiding paying it. The aim of the article is to examine the awareness assessment of students of the University of Lodz about economic and legal trends regarding carousel crimes, which cause a budget gap and a threat to honest entrepreneurs depriving them of input tax deductions. The article puts forward the following research hypothesis, whether the current curriculum in economics and law faculties of the University of Lodz is sufficiently adequate and adequately makes students aware of the mechanism used by dishonest entrepreneurs. Studies were carried out among students of the University of Lodz, studying economic and legal studies. The study attempts to assess whether the current teaching program of the University of Lodz provides relevant knowledge regarding carousel tax. Students of economics and law faculties should be prepared for such situations and allergic to thorough verification of new contractors. Knowing the mechanism of extortion of the tax on goods and services using the carousel method, the phenomenon occurring in the economy, not only in Poland, but also in Europe, will be significantly reduced.
\end{abstract}

Keywords: carousel, VAT tax, University of Lodz, tax due, input tax. 